\title{
Women's Political Rights in Islamic Law Perspective (Analysing the Implementation in Indonesian Political System)
}

\author{
Fatmawati $^{1}$, Muhammad Shuhufi ${ }^{2}$ \\ Lecturer of Ilmu Fiqih Siyasah in Syariah and Law Faculty of UIN Alauddin Makassar, \\ Indonesia $^{1,2}$ \\ \{fatmawati@uin-alauddin.ac.id ${ }^{1}$, shuhufi@yahoo.com $\left.{ }^{2}\right\}$
}

\begin{abstract}
This paper will address women's political participation in politics, especially in politics actively, such as parliamentarians, although politics can be broad-based. This is because the position of women as leaders or as legislators is often disputed. The participation of women in parliament, with a hectic schedule, mingle with men, and so on is very time-consuming outdoors. At the same time, having abandoned his role and function as wife and mother of his children is a pretext used to sue women's participation in practical politics. This is the reason that politics as the world of men, so the involvement of women is still considered some people as unusual for women. Islam has given guidance in life. Men and women have the same right to participate in politics, as one part of the implementation of God's trust, khalifatullah fil area. Classical and modern scholars differ on the political rights of women. This difference relates to their respective concepts of the character of this field. The earlier scholars put the issue of general freedom which meant elemental powers such as the rule-making power, in contrast to contemporary scholars who emphasize the equality of rights.
\end{abstract}

Keywords: Woman, Political Right, Islamic Law

\section{Introduction}

The political field is the right of citizens to participate in governing the state. This participation can be directly or indirectly involving citizens directly involved in political affairs, such as holding ministerial positions, members of the parliament and other important positions, In this case, the voter means to have participated - indirectly - in politics. The indirect way is the participation of citizens in political affairs, not as officials in government who are bound by their political rules, but as the choice of the community in the place of work, such as the head of neighborhood and citizens; positions in universities, and other community organizations.

In general, there are differences of opinion about the validity of women when serving in the political area. Opinions that allow women to politics assume that women have the right to involve themselves in political leadership based on the principle of democracy that men and women have equal rights in rights and duties without questioning gender, ethnicity or belief. Opinions and insights relating to women's political rights are three views: First, it states that Islam forbids women from becoming directly involved in politics; Secondly, it states that there 
is no prohibition for women to engage in politics; and Third, the view that the political issue for women is not related to religion or law, but merely just a social and political field.

\section{Literature review}

Political according to the broad definition is not only a government's policies at home and abroad but included in the policies of the smallest institutions -like household[1]. Politics or siyasa is a way of managing the affairs of life together to achieve the prosperity of the world,and the hereafter[2], [3]Politics is a very large field, as large as the living space itself. It appears in the domestic as well as the public, cultural and structural, personal and communal. However, in its development, politics has a narrower meaning to the term political, practical, structural politics, power struggles for self-interest or some people and a moment, not for the benefit of the wider community and the long-term future.

Politics in the narrow definition means the responsibility of regulating and maintaining the affairs of the ummah and the whole society[4]. Practical politics according to the Islamic Shari'a is politics which does not reveal power struggles, cruelty, injustice, because Islam lays the foundation of governing and maintaining the affairs of the people by God's laws, not on the dictatorship of the ruler or the desire of a group of people. Rulers are only political implementers who are sourced from the laws of Allah swt, while the community acts as an actor and corrector of political life to be in the way of Shari'ah law.

In the present conditions, when the field of work is no longer dominated by a person's physical strength, Women have had many opportunities to find work according to their expertise[5]. The understanding that men are leaders for women creates a negative perception of women's position, making men superior to women. While women only as male (husband) servants and raises the perception that women can be treated what the word (desire) of her husband because her life is entirely dependent on the husband[6]

Such negative assumptions have become public opinion due to the first opinion built by history[7]. During the time, there has been a developing mindset that forms a stereotypical view of women. The stereotype formed by this history is reinforced by the mass media, thereby actually cornering women[8]. This raises a unilateral formula that results in discrimination against women and other injustices. Many stereotypes are attached to society by women that result in limited space for women's activities.This, in turn, shapes the behavioral patterns and attitudes of women who are implemented into the unchangeable nature of women. This mindset is so strongly shaped and became a kind of religious teachings that have developed in society today[9]. This view is often reinforced by an imperfect understanding of religious teachings, both from the Qur'an and the hadith. It is interesting to examine women's political rights and their relationship with the political system in Indonesia.[10]

\section{Method}

This research is qualitative descriptive research method, that is by doing a study on political concepts according to Islamic law which has been formulated in fiqihsiyasah (Islamic political law), thenanalyzed by the inductive and deductive method to produce the formula of the relationship between a political concept in Islamic law and political concepts in Indonesia.

The data is collected from references on women's political rights, both according to Islamic law and references on the implementation of women's political rights in Indonesia, so it is 
expected to provide an overview of the possible implementation of women's political rights in Indonesia in accordance with Islamic law.

\section{Result and discussion}

In general, in Islamic fiqhliterature, there are three opinions about the involvement of women in politics. First, Opinions that prohibit and opinions that allow women involved in politics[11][12].Second, opinions that forbid women to engage in politics base their views on the understanding of Quranic verses and hadith using textual methods, for example in verses of the Qur'an Surah al-Nisa verse 228 which asserts that men are leaders for women and some facts indicate that women in the Muhammad SAW. Did not occupy an important position in politics. Third, the view that the political issue for women is not related to religion or law, but rather a social and political problem a sich

Another argument is by the method of qiyas/analogy expressed by taking some Islamic teachings about the prohibition for women, such as not being a leader for the general public in the Five Daily Prayers, the Friday Prayers, and the 'Id Prayer, the women have no right to determine the divorce (talaq), women should not travel alone without the muhrim or trusted friends, and women are not required to pray in the congregation jum'ah praying. It is for this reason that it is then equated with the political field for women, so it is concluded that women should not pursue the political field.

Opinions that allow women to participate in politics base their views on QS.al-Nisa(4): 1 and 32 and QS. al-Taubah (9): 71, is generally a description of the obligation to cooperate between men and women in various spheres of life. The command of amarma'rufnahymunkarcovers every aspect of goodness and improvement of human life. Therefore, men and women must always actively follow the development of society, to contribute thoughts to the development of the times, in all aspects of human life, not least in the political field.

The above differences can be understood as a result of differences in understanding or interpretation of religious texts and the different methods of understanding them[13]. So, there is only a textual understanding and some who understand contextually.

In relation to women's political participation in Indonesia, especially in a narrower scope, such as parliamentarians. This is because the position of women as leaders -as legislators- is often debated. Practical politics is regarded as a field of men, so the participation of women is still regarded as something unusual. Islam has given guidance in living life, men and women have equal rights to participate in politics, as God's trust.

Political work is the right of citizens to take part in taking care of state affairs. This participation can be either direct or indirect. The direct way is that citizens directly deal with political affairs not by representing others, such as holding ministerial posts and other important positions, as well as the positions of representatives of the people's assembly when elected as their delegates. Women's involvement indirectly in the political field such as participating in elections[14]

Those who deny the women right of membership in parliament but agree to their right to vote in their various forms, membership rights in universities, members of local social organizations and Majlis, refer to the principle that equality in law and constitution is not an equality between two unequal groups, but the similarity between the equations. Women are not the same as men in everything. Therefore the state has the authority to limit the sources of legislation between the same and the unequal. The principle of equality is when citizens have in common with other citizens in skills, conditions, and experience. If the conditions of 
equality have been established in the individual, then he/she deserves to have this right. If the factors and conditions are different from one and the other, then the equation can't be given.

In the Arab region, there is a fierce debate about women's right to take part in the political association represented in the electoral rights and sitting in Parliament. Some women activists in political activity assume that this right is the key that will open for women all honor and glory. Therefore it is held in particular, various conferences and meetings to discuss the issue of political rights for women.

Various women's associations think that the inclusion of women in Parliament will solve all women's political and social backwardness; become the secret key for solving various problems faced by women.[4]

In the Islamic perspective, Islam is a mercy for all nature, all creation and grace for men as well as women. Islamic teachings want to raise the dignity, dignity, and degree of human, both male and female. Rights and duties are granted to men or women. In the context of worship and charitable deeds that have beneficial effects for the ummah, both men and women have the same duty to do so.

The coming of Islam is not intended as a re-history of restraint, restriction,and placement of women in unnatural positions. Islam provides the widest opportunity for its followers to create prosperity and justice on earth. Islam also provides an opportunity to participate in the world enlightenment process. There are no restrictions that restrict the followers of Islam to do any good. In the Islamic perspective, all human activities are regarded as a duty of obligation, which is subsequently divided into fardhu 'ain (individual obligation) and fardhukifayah (collective duty). In general, the duties, both fardhu 'ain andfardhukifayah are closely related to human capabilities, so these tasks become compulsory for those who are capable of fulfilling them since religion will not force a person except according to his ability.

Likewise, political activities are regarded as tasks, and therefore can be classified into fardhu 'ain such as baiat or oath of allegiance and shura or deliberation, and become fardhukifayah like jihad, government office,andamarma'rufnahimunkar. The obligation of these activities, including politics, is based on the concept of God's representation or manifestation on earth (khilafah), which includes both men and women and calls for individual and collective responsibility to fulfill God's commandments on earth. So men and women are equal partners, sharing responsibilities or duties for political affairs in society because they are partners in telling the good and forbidding evil.

All the work of the judicial, executive and legislative authorities is to carry out the command to do good and prevent evil. Therefore, as men, Muslim women have broad political responsibility and an important role in public life, a role that has been given to serving the Islamic community in Medina and for some time afterward in the early period of Islam. Especially during the time of the Prophet, women were very active in social and political fields. They are allowed even encouraged to participate in the development process of Medina society, and they are proven to carry out the task. Muslim women begin their political activities when they convert to Islam. They defend their newly embraced religion by facing fierce opposition from their own families and from the wider community. When they are under enormous pressure, they decide to leave home, to seek refuge with their fellow Muslims rather than abandon belief and faith

All of these behaviors are perceived as political activities in the contemporary term, and are against the old political system, protesting against harassment, torture, and rejection of an emphasis on political engagement. In these circumstances, women's role in political affairs in the new society is gaining momentum. Women become part of effective members of the nation and members of the community, participating fully in public affairs 


\section{Conclusion}

From this discussion, it can be concluded that the involvement of women in politics according to Islamic law is not an absolute prohibition, but its prohibition relates to things that prevent women from carrying out their main duties such as housewives. The view that women in the subordinate of men are strongly influenced by pre-Islamic views. Therefore, in the present, there is no longer any reason to forbid women to be active in politics, especially in the political system in Indonesia

\section{References}

[1] B. Miriam, Dasar-dasar Ilmu Politik. Jakarta: Gramedia, 1982.

[2] Q. Z. Abdul, Al-Afkar al-Siyasi. Beirut: Dar al-Ummah.

[3] S. Najmah and H. Khatimah, Revisi Politik Perempuan: Bercermin pada Shahabiyat ra. Bogor: Idea Pustaka, 2003.

[4] A. Q. H. Tijani, Pemikiran Politik Al-Qur'an. Jakarta: Gema Insani Press, 2001.

[5] Kelik Wardiono; Wafda Vivid Izziyana, "Pekerja Imigran Perempuan dalam Perspektif Islam,” Istawa J. Pendidik. Islam, vol. 3, no. 2, pp. 1-24, 2018.

[6] S. Zaitunah, Tafsir Kebencian: Studi Bias Gender dalam Tafsir Al-Qur'an. Yogjakarta: LKis, 1999.

[7] A. Ikhwan, "Kajian Sosio-Historis Pendidikan Islam Indonesia Era Reformasi," Edukasi J. Pendidik. Islam, vol. 5, no. 1, p. 17, 2017.

[8] M. L. Hillary, Sex and Gender an Introduction. USA: Mayfield Publishing Company, 1992.

[9] A. Ikhwan, Filsafat Pendidikan Islam: Memahami Prinsip Dasar. Yogyakarta: Diandra Kreatif, 2018.

[10] F. Mansour, "Membincang Feminisme: diskursus gender perspektif Islam," Surabaya: Risalah Gusti, 1996.

[11] U. t. t. Said, Al-Nizam al-Dusturi al-Mishri. Alexandria, Egypt: Munsha'ah al-Mu'arif, 1980 .

[12] H. A. t. th. Abdul, Al-Huq-q al-Siysiyyah li al-Mar'ah fi al-Islam. Iskandariah: Dar Mansya'ah al-Ma'arif.

[13] A. Ikhwan, "Dinamika Kajian Islam di Indonesia dan Malaysia," in The Development of Islamic Studies in Indonesia and Malaysia International Seminar, 2014, pp. 263 276.

[14] A. A.-B. Salim, Wawasan Sistem politik Islam. Jakarta: Pustaka al-Kautsar, 1996. 